\title{
Effects of Model Layer Simplification Using Composite Hydraulic Properties
}

\author{
Nicasio Sepúlveda and Eve L. Kuniansky \\ U. S. Geological Survey \\ United States
}

\section{Introduction}

Groundwater provides much of the fresh drinking water to more than 1.5 billion people in the world (Clarke et al., 1996) and in the United States more that 50 percent of citizens rely on groundwater for drinking water (Solley et al., 1998). As aquifer systems are developed for water supply, the hydrologic system is changed. Water pumped from the aquifer system initially can come from some combination of inducing more recharge, water permanently removed from storage, and decreased groundwater discharge. Once a new equilibrium is achieved, all of the pumpage must come from induced recharge and decreased discharge (Alley et al., 1999). Further development of groundwater resources may result in reductions of surface water runoff and base flows. Competing demands for groundwater resources require good management. Adequate data to characterize the aquifers and confining units of the system, like hydrologic boundaries, groundwater levels, streamflow, and groundwater pumping and climatic data for recharge estimation are to be collected in order to quantify the effects of groundwater withdrawals on wetlands, streams, and lakes. Once collected, three-dimensional (3D) groundwater flow models can be developed and calibrated and used as a tool for groundwater management. The main hydraulic parameters that comprise a regional or subregional model of an aquifer system are the hydraulic conductivity and storage properties of the aquifers and confining units (hydrogeologic units) that confine the system.

Many 3D groundwater flow models used to help assess groundwater/surface-water interactions require calculating "effective" or composite hydraulic properties of multilayered lithologic units within a hydrogeologic unit. The calculation of composite hydraulic properties stems from the need to characterize groundwater flow using coarse model layering in order to reduce simulation times while still representing the flow through the system accurately. The accuracy of flow models with simplified layering and hydraulic properties will depend on the effectiveness of the methods used to determine composite hydraulic properties from a number of lithologic units.

The computation of the composite transmissivity for heterogeneous aquifers was presented for steady flow by Copty et al. (2006) by using a weighted average of the log transforms of the locally measured transmissivity within the aquifers. This probabilistic approach leads to a large-scale transmissivity that is approximately equal to the geometric mean of local transmissivity. The large-scale transmissivity has been shown to be larger than the geometric mean of local tests at site-specific studies (Sánchez-Vila et al., 1996). Simplification 
of model layers with composite hydraulic properties is not always feasible (Wen \& GómezHernández, 1996). Calculation of composite hydraulic properties has been mostly limited in the literature to hydraulic conductivity and transmissivity. Feng et al. (2007) computed composite hydraulic conductivity using the constant-flux assumption of Darcy's law within a finite-difference block by integrating, over the thickness of the block, the effective pressure-head dependent hydraulic conductivity divided by the head difference within the block. Parameter estimation of hydraulic properties through inverse modeling was used by Ward et al. (2006) to derive the composite hydraulic conductivity in the unsaturated zone.

This chapter evaluates the effects of simplifying hydraulic property layering within an unconfined aquifer and confining unit system that overlies a deeper confined aquifer, which is the principal water supply. This goal is accomplished in three steps. First, reference values of hydraulic properties are derived for all of the lithologic units identified in the unconfined aquifer and confining unit at two well fields in central Florida (USA) through inverse modeling of aquifer-test data. Second, simplified representations of the referenced lithologic units at the well fields are constructed by computing composite hydraulic properties for several aggregated units from the reanalysis of the aquifer-test data. Finally, the effects of lithologic simplification and the performance of the methods used to compute composite hydraulic properties are evaluated using fully 3D and quasi-3D flow models in which the number of lithologic units is gradually reduced. The most effective composite flow model is identified from flow residuals. A shallow and a deep well field in the surficial aquifer system (SAS) were selected to conduct aquifer tests to define a hydraulic conductivity field with the highest resolution possible.

Four multi-observation-well aquifer tests at two well fields were conducted and analyzed. The head data and the hydraulic properties determined for the two well fields from the analysis of the aquifer-test data were used to develop several conceptual 3D groundwater flow models by gradually using fewer layers to determine acceptable levels of layer simplification for simulation of water levels and leakage rates at the two well fields. Additionally, quasi-3D flow models were compared to fully 3D models (McDonald \& Harbaugh, 1988) to assess the effects of assuming only a vertical flow component (quasi-3D) versus allowing both vertical and horizontal flow components in the leaky confining unit (fully 3D). The reader is referred to Harbaugh et al. (2000) for further details establishing the difference between these two conceptual flows.

Results of simulated flows and heads with a simplified number of layers are compared to those simulated with the most discretized set of hydraulic properties derived from the aquifer-test data analyses to assess the feasibility of preserving the main flow features with a simplified layering model. Multiple flow simulations generated from the methods of calculating composite hydraulic properties are compared to identify potentially unrealistic conceptual flows. This comparison allows a quantitative assessment of the simulated flow residuals introduced by the simplification.

\section{Derivation of preliminary hydraulic parameters through slug-test data analyses}

The SAS, composed mostly of sand, silt, clay, and gravel, is the uppermost water-bearing unit in most of central Florida and overlays the Floridan aquifer system (FAS). Slug tests were performed in two well fields in the SAS; one named Carrot Barn located in northwest Lake County and another one named Lyonia Preserve located in southwest Volusia County, 
Florida (Fig. 1). The analyses of the slug test data resulted in the derivation of horizontal hydraulic conductivity from water-level displacement data recorded after introducing or withdrawing a closed cylinder to or from the wellbore. The stress exerted on the aquifer by the removal or injection of a closed cylinder is considered small as it involves no pumping and thus, the hydraulic conductivity values obtained from the analysis of slug test data apply to a maximum of 1 to 2 meters of open interval to the aquifer. The length of this open interval is considered to be of limited spatial range when compared to an aquifer test where the production well stresses a larger percentage of the aquifer thickness; a percentage that depends on the design of the production well.

(a)

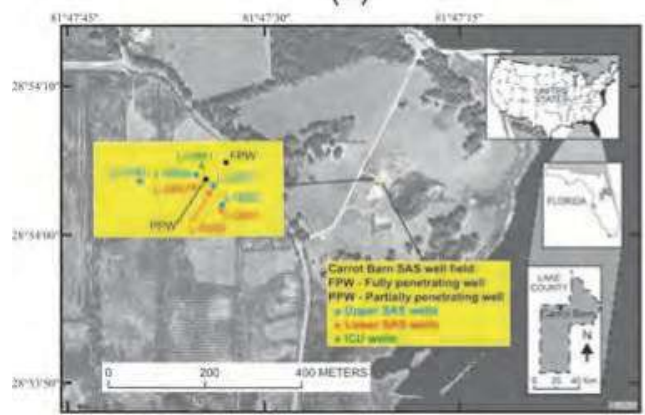

(b)

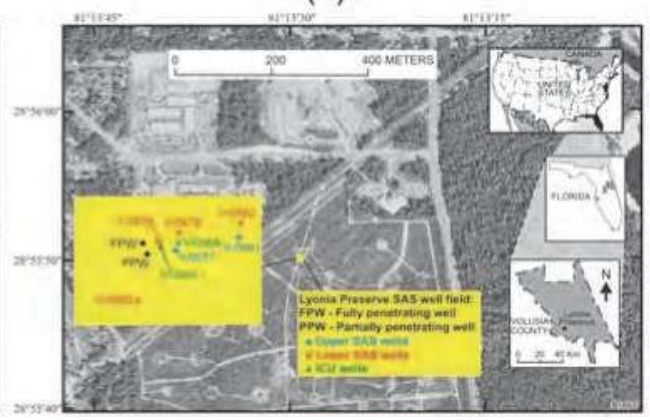

Fig. 1. Locations of the surficial aquifer system well fields in (a) Carrot Barn, Lake County and Lyonia Preserve, Volusia County, Florida.

Aquifer responses to slug tests are classified depending on the shape of the graph of the water levels as they return to equilibrium after the injection or removal of the closed cylinder. Responses are classified as overdamped (Bouwer \& Rice, 1976) when the water levels return to equilibrium following the shape of a slowly decaying exponential, or as underdamped (Van der Kamp, 1976) when the water levels vary sinusoidally while returning to equilibrium. Hydraulic conductivity values resulting from the analyses of underdamped aquifer responses are greater than those from overdamped responses. While an overdamped aquifer response to a slug test is typical for a clay, silt, fine silty sand, or low porosity limestone, an underdamped aquifer response can occur for gravel, well-sorted sand, or karstified limestone (media with large diffusivity, defined as transmissivity divided by storage). Underdamped water-level responses were recorded at wells L-0892, L-0894, and L-0901 (Fig. 2a) and in wells V-0876, V-0877, V-0878, V-0881, V0882, and V-0883 (Fig. 2b). Overdamped responses were recorded at the remaining wells shown in figure 2.

Results of the horizontal hydraulic conductivities from slug test data are shown in the cross sections in figure 2 . These hydraulic conductivity values derived from the slug tests analysis correspond to the immediate vicinity of the well open to the aquifer. These values are compared to those obtained from the drawdown analysis of aquifer test data, which correspond to a much larger spatial scale than that reflected by slug tests. In turn, these aquifer test results are then compared to regional hydraulic conductivity values derived from groundwater flow simulation to provide a perspective of scale variability under regional flow. 


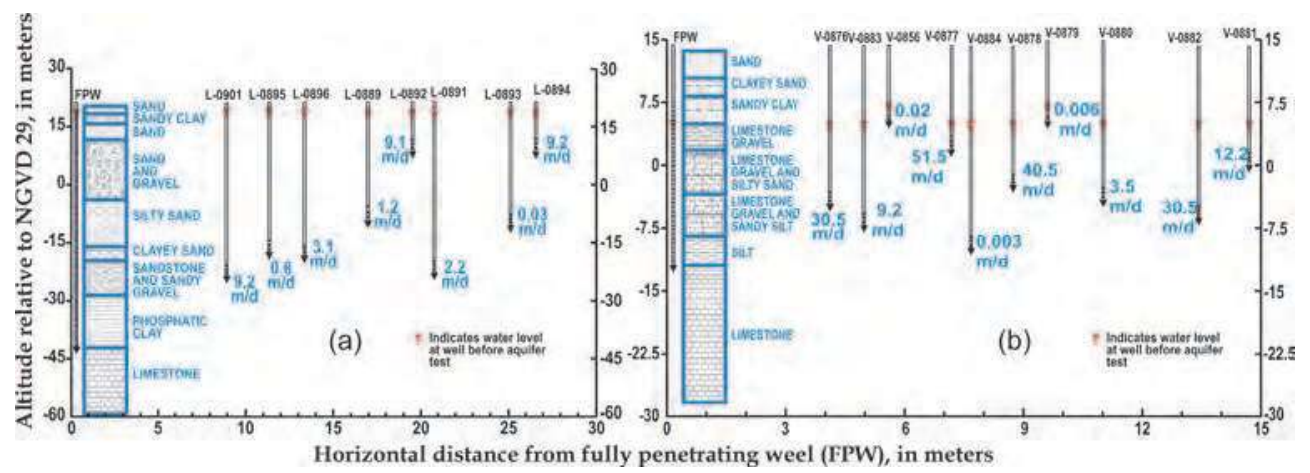

Fig. 2. Lithologic units identified in the fully penetrating well (FPW) and hydraulic conductivity values derived from slug tests performed at open intervals of (a) Carrot Barn SAS wells and (b) Lyonia Preserve SAS wells, in meters per day. [Altitudes refer to the National Geodetic Vertical Datum (NGVD) of 1929 (Snyder, 1987)]

The complexity of the intricate layering shown in figure 2 is exemplified by the relatively wide range of hydraulic conductivity values derived from slug tests. Analysis of drawdown data derived from larger scale aquifer tests can result in hydraulic conductivity values that depict a more regional perspective than the highly discretized layering properties shown in figure 2 .

\section{Derivation of reference hydraulic properties through aquifer-test data analyses}

Multi-observation well aquifer tests were conducted at the Carrot Barn and the Lyonia Preserve well fields (Fig. 1). Wells open to the SAS, an unconfined aquifer, were pumped to determine the hydraulic properties of all lithologic units identified above the generally confined Upper Floridan aquifer (UFA). These lithologic units were identified while drilling fully (FPW) and partially penetrating production wells (PPW). Aquifer tests for both FPW and PPW were conducted to generate the drawdown data that allow the computation of most hydraulic properties. When the entire aquifer thickness is stressed by pumping from the FPW, a predominantly radial flow is generated towards the well. Such flow generally allows the calculation of the hydraulic properties of all the lithologic units identified in the SAS, with the exception of the vertical hydraulic conductivity. The calculation of the vertical to horizontal hydraulic conductivity ratio of the lithologic units in the SAS can be obtained from the aquifer response to pumping from a PPW (Hantush, 1964) because such stress generates a non-negligible vertical flow component towards the well.

The SAS overlies a leaky confining unit called the intermediate confining unit (ICU). Observation wells tapping the SAS in a shallow water-table setting (Carrot Barn well field, Fig. 1a) and in a deep water-table setting (Lyonia Preserve well field, Fig. 1b), were screened to the upper, middle, and lower depths of the SAS and to the ICU to isolate the water-level response at these depths. Flow in the SAS and ICU at each one of these well fields should be regarded as independent flow subsystems of the larger SAS, ICU, and UFA flow system in east-central Florida because of the different number of lithologic units within the SAS and ICU identified at these two well fields. 
Although the SAS is generally unconfined with discontinuous clay lenses that make this aquifer semiconfined in some areas. The SAS consists predominantly of fine-to-coarse grained quartz sand with varying amounts of silt and clay. The sediments in the SAS generally grade into less permeable silty or clayey sands with increasing depth. The ICU is composed primarily of phosphatic clays, silts, and sands. The ICU separates the SAS from the UFA, which is composed of fractured carbonate rocks (Miller, 1986). The UFA is the major aquifer used for water supply in Florida.

Four aquifer tests were conducted, two at each well field, by pumping the FPW and PPW during separate tests. Each aquifer test began after water levels had reached static equilibrium. At the Carrot Barn well field, both FPW and PPW were pumped at $5.8 \times 10^{-3}$ $\mathrm{m}^{3} / \mathrm{s}$ for 70 hours. At the Lyonia Preserve well field, the FPW was pumped at $6.2 \times 10^{-3} \mathrm{~m}^{3} / \mathrm{s}$ for 67 hours and the PPW was pumped at $4.5 \times 10^{-3} \mathrm{~m}^{3} / \mathrm{s}$ for 30 hours. Pumping rates for each test were constant. Horizontal and vertical hydraulic conductivity, specific yield, and specific storage at various depths in the SAS and ICU were determined at each well field.

Walton (2008) contends that multiple observation well aquifer tests should be analyzed with more sophisticated techniques, such as the use of numerical models with regression-based parameter estimation techniques. The four tests were analyzed by developing radial, axisymmetric groundwater flow models. Radial axisymmetric models are typically used to approximately simulate 3D flow to wells (Reilly \& Harbaugh, 1993; Langevin, 2008). The computer code MODOPTIM (Halford, 2006), based on MODFLOW-96 (Harbaugh \& McDonald, 1996), was used to derive the hydraulic properties for each lithologic unit using regression-based parameter estimation techniques to minimize the sum of square residuals (SSR) between measured and simulated drawdown (Figs. 3, 4). Analysis of the lithologic data from drilling the FPW and PPW at the Carrot Barn well field identified five individual lithologic units in the SAS and one lithologic unit in the ICU (Fig. 5a). A similar analysis of data from the Lyonia Preserve well field indicated the presence of three lithologic units in the SAS and one lithologic unit in the ICU (Fig. 5b).

The Carrot Barn well field has an average land surface altitude of about $20 \mathrm{~m}$ above the NGVD of 1929 with the farthest well about $27 \mathrm{~m}$ away from the FPW. The Lyonia Preserve well field has an average land surface altitude of $14 \mathrm{~m}$ above the NGVD of 1929 with the farthest well about $15 \mathrm{~m}$ away from the FPW. The aquifer tests were designed to derive hydraulic properties at the local scale of the well fields and the numerical grids used to simulate flow in these well fields were spaced radially to consider the same local scale.
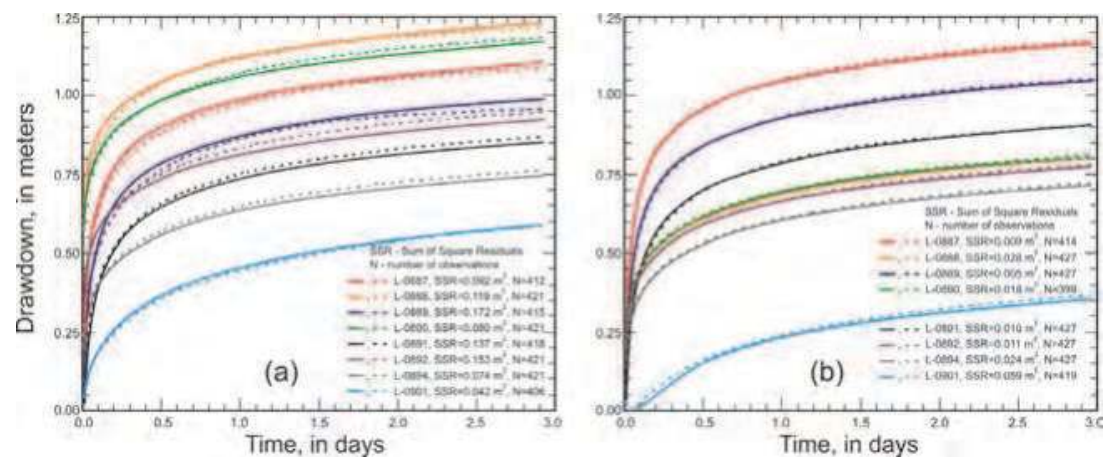

Fig. 3. Simulated (solid lines) and measured (dashed lines) water levels at observation wells in the Carrot Barn well field after pumping from the (a) FPW and (b) PPW. 

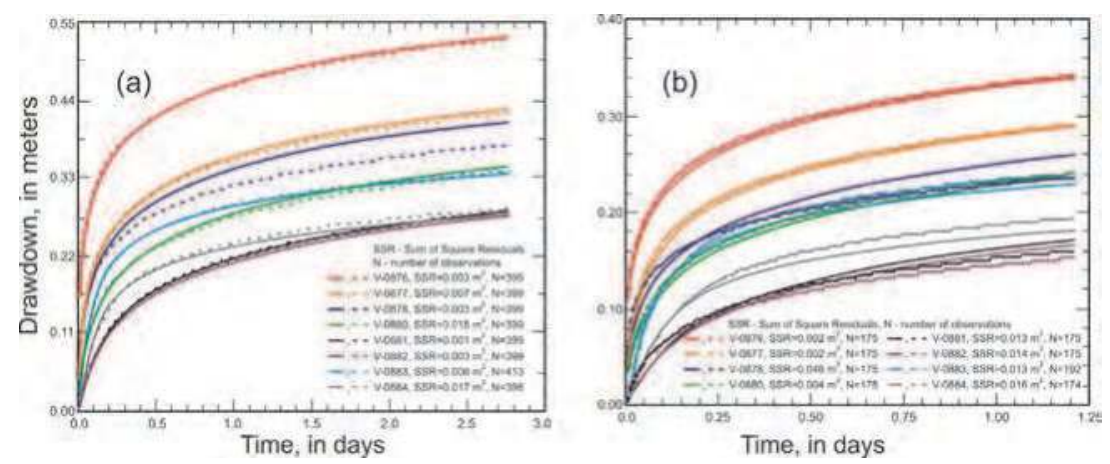

Fig. 4. Simulated (solid lines) and measured (dashed lines) water levels at observation wells in the Lyonia Preserve well field after pumping from the (a) FPW and (b) PPW.

The model grid used for the analysis of the aquifer-test data consisted of rows of uniform thickness of $0.305 \mathrm{~m}$ in the SAS, ICU, and UFA (vertical discretization) with a uniform hydraulic property assigned to each model layer (row) representing the lithologic unit identified in figure 5 . The number of rows in each model grid can be calculated by dividing the thicknesses of the lithologic units shown in figure 5 by $0.305 \mathrm{~m}$. A high resolution vertical grid was used to minimize truncation errors in the simulated heads in each layer. The column spacing (radial distance from the well) consisted of 150 columns that gradually increased in width from 0.12 to $2,593 \mathrm{~m}$ for a total distance of $40,234 \mathrm{~m}$, extending beyond the radius of influence for the pumping rates applied in each test. There was no rainfall during any of the aquifer tests and thus, no-flow boundaries were imposed at the top of the SAS and at the lateral boundary away from the well. Models were calibrated to measured drawdown. The high transmissivity of the UFA and the fact that only the SAS was pumped were the reasons for choosing a constant-head boundary at the bottom of the UFA layer.

The computation of the hydraulic properties for all lithologic units identified in the SAS represents the highest vertical discretization of layers for the Carrot Barn (Fig. 5a) and Lyonia Preserve (Fig. 5b) well fields. Specific yield, computed only for the uppermost layer of the SAS, was 0.118 and 0.266 for the Carrot Barn and Lyonia Preserve well fields, respectively. These specific yield values were applied to the uppermost layer of the SAS in all subsequent simplified conceptual flow models. Specific yield values determined from the aquifer-test data for the uppermost simulated layer were kept constant from one simplified model to another as the specific yield used for the uppermost simulated layer.

Pumping from the SAS did not cause measurable drawdown in the UFA, thus, hydraulic properties for the UFA could not be estimated from the aquifer-test drawdown data. The simulated horizontal hydraulic conductivity for the UFA at the Carrot Barn $(30.1 \mathrm{~m} / \mathrm{d})$ and Lyonia Preserve $(82.5 \mathrm{~m} / \mathrm{d})$ well fields were obtained from model-simulated values reported by McGurk \& Presley (2002). These hydraulic properties for the UFA are not used in the simulated layer simplification process because composite hydraulic properties are derived only for the lithologic units in the SAS and ICU. Vertical hydraulic conductivities were obtained by assuming a vertical to horizontal hydraulic conductivity anisotropy ratio of 0.01 because such a ratio is the most prevailing in the UFA flow simulations in eastcentral Florida (McGurk \& Presley, 2002; Sepúlveda, 2002). Specific storage for the UFA (Fig. 5) was assigned based on water and limestone compressibility values (Domenico, 1972). 


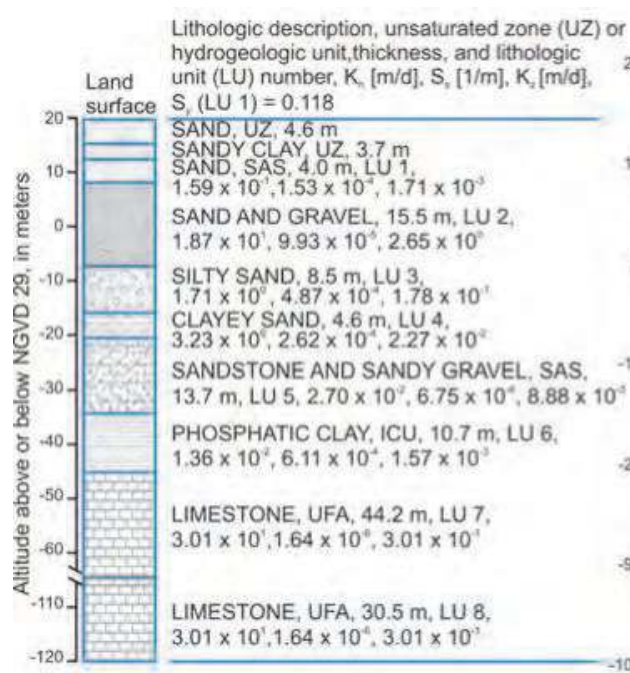

(a)
Lithologic description, unsaturated zone (UZ) or hydrogeologic unit,thickness, and lithologic unit (LU) number, $K_{,}[\mathrm{m} / \mathrm{d}], \mathrm{S},[1 / \mathrm{m}], \mathrm{K}_{ \pm}[\mathrm{m} / \mathrm{d}]$.

\section{Land} surface $\mathrm{S},(\mathrm{LU} 1)=0.266$

SAND, UZ, $6.4 \mathrm{~m}$

CLAYEY SAND, UZ, $4.6 \mathrm{~m}$ LIMESTONE GRAVEL, SAS SANDY CLAY UZ, $3.6 \mathrm{~m} \quad 1.5 \mathrm{~m}$, LU $1,6.57 \times 10$ $1.5 \mathrm{~m}, \mathrm{LU} 1,6.57 \times 10^{\circ}$
$4.91 \times 10^{-1}, 3.29 \times 10^{6}$ LIMESTONE GRAVEL AND SILTY SAND, SAS, $4.9 \mathrm{~m}$, LU 2, $6.82 \times 10^{\prime}, 4.91 \times 10^{\prime}, 6.14 \times 10^{\circ}$ LIMESTONE GRAVEL. AND SANDY SILT, SAS. $2.7 \mathrm{~m}$, LU $3,4.96 \times 10^{\circ}, 7.13 \times 10^{\circ}, 5.95 \times 10^{\circ}$ SILT, ICU, $4.9 \mathrm{~m}$, LU 4 $4.38 \times 10^{5}, 9.08 \times 10^{4}, 4.38 \times 10^{4}$

LIMESTONE, UFA, $56.4 \mathrm{~m}$, LU 5 , $8.25 \times 10^{\prime}, 1.64 \times 10^{6}, 8.25 \times 10^{1}$

LIMESTONE, UFA, $30.5 \mathrm{~m}$, LU 6 , $8.25 \times 10^{\prime}, 1.64 \times 10^{-1}, 8.25 \times 10^{\prime}$

Fig. 5. Highest possible lithologic unit discretization within the SAS at (a) Carrot Barn well field and at (b) Lyonia Preserve well field and hydraulic properties derived from the analysis of aquifer-test data. The abbreviated vertical axis indicates relatively thick layers.

A comparison of the horizontal hydraulic conductivities derived from the analysis of slug test data for the cross sections in figure 2 and those hydraulic conductivity values derived from the analysis of aquifer test data for the appropriate lithologic units in figure 5 indicate a trend in the relation between these two sets of values. At the Carrot Barn well field, average hydraulic conductivity values from slug test data for wells with open intervals to lithologic units 2 to 5 in the SAS were 9.15, 0.62, 1.85, and 5.7 meters per day, respectively. The corresponding hydraulic conductivity values derived from the aquifer tests for the same lithologic units were 18.7, 1.71, 3.23, and 13.7 meters per day (Fig. 5a). At the Lyonia Preserve well field, average hydraulic conductivity values from slug test data for lithologic units 1 to 3 in the SAS were 51.5, 26.4, and 18.4 meters per day, respectively. The corresponding hydraulic conductivity values derived from the aquifer tests for the same lithologic units were 65.7, 68.2, and 49.6 meters per day (Fig. 5b). The consistently higher hydraulic conductivity values derived from the aquifer tests indicate a slightly larger scale of flow is accounted for over a larger area to better represent flow more areally extensive. The different magnitudes and scales of aquifer stresses generated by slug and aquifer tests result in different hydraulic conductivity values. The identification of this variability in hydraulic conductivity resulting from slug tests and aquifer tests is a result of the high degree of discretization used to identify the vertical extent of uniform soil grains of each lithologic unit as shown in figures 2 and 5.

\section{Derivation of composite hydraulic properties for simplified model layering}

Composite hydraulic properties for simplified model layering can be derived by computing equivalent hydraulic properties for aggregated layers using several methods. The first method presented in this chapter is to compute the thickness weighted average horizontal 
hydraulic conductivity and specific storage and the thickness weighted harmonic mean vertical hydraulic conductivity for a reduced number of layers in the unconfined aquifer and the leaky confining unit. The second method is to compute hydraulic properties by using the observed head from aquifer tests and applying the regression-based parameter estimation (PE) techniques (Poeter et al., 2005; Halford, 2006; Hill \& Tiedeman, 2007). As the number of simulated layers in the unconfined aquifer is decreased, the performance of each model is assessed by analyzing changes in simulated heads under aquifer test conditions and by simulating flow exchanges between the hydrogeologic units under hypothetical but realistic recharge rates to the unconfined aquifer and withdrawals from the confined aquifer.

Composite horizontal hydraulic conductivity $K_{h c}$, and vertical hydraulic conductivity $K_{z c}$, and specific storage $S_{s c}$, from any set of $L$ lithologic units (LUs) are calculated from the equations:

$$
\begin{gathered}
K_{h c}=\frac{K_{h 1} b_{1}+K_{h 2} b_{2}+\cdots+K_{h N} b_{L}}{b_{1}+b_{2}+\cdots+b_{L}}, \\
K_{z c}=\frac{b_{1}+b_{2}+\cdots+b_{L}}{\frac{b_{1}}{K_{z 1}}+\frac{b_{2}}{K_{z 2}}+\cdots+\frac{b_{L}}{K_{z L}}} \text {, and } \\
S_{s c}=\frac{S_{s 1} b_{1}+S_{s 2} b_{2}+\cdots+S_{s L} b_{L}}{b_{1}+b_{2}+\cdots+b_{L}},
\end{gathered}
$$

where $b_{1}, b_{2}, \cdots$, and $b_{L}$ are the thicknesses; $K_{h 1}, K_{h 2}, \cdots$, and $K_{h L}$ are the horizontal hydraulic conductivity; $S_{s 1}, S_{s 2}, \cdots$, and $S_{s L}$ are the specific storage; and $K_{z 1}, K_{z 2}, \cdots$, and $K_{z L}$ are the vertical hydraulic conductivity of each LU. Eqs. (1) and (2) are derived in Bouwer (1978). Assuming that the porosity and water density remain nearly constant among layers, Eq. (3) states that aquifer matrix compressibility can be averaged over layer thickness, thus it mimics the form of Eq. (1). Note that Eq. (3) is not used to estimate the specific yield of the uppermost layer of the unconfined aquifer because specific yield, being several orders of magnitude greater than specific storage multiplied by layer thickness, was used for the uppermost layer of the SAS in all conceptual flow models.

Composite hydraulic properties from an arbitrary number of layers using PE techniques are derived in this chapter by minimizing the normalized residuals between the measured drawdown during the aquifer tests and the simulated drawdown by models where several LUs become a single composite layer. The head residuals in the unconfined aquifer are used to determine if the main flow features in this aquifer are preserved by each simplified conceptual flow model with the use of a radial, axisymmetric 2D flow model. The feasibility of each simplified model to preserve the main flow features in both the unconfined and confined aquifers requires a 3D groundwater flow model that simulates recharge to the unconfined aquifer and withdrawals from the confined aquifer.

The heads in the SAS, in the ICU, in the UFA, and the leakage rates to the UFA are the observations used to assess the accuracy of the simplified conceptual flow models by comparing these flow characteristics with those simulated by the highly discretized model. If $\mathrm{Di}$ and $\mathrm{Si}$ are subscripts used to denote flow parameters in the highly discretized model 
and the simplified conceptual flow model with a decreased number of layers, respectively, then dimensionless head and leakage rate residuals can be calculated from:

$$
\sum_{i=1}^{N}\left(\frac{h_{S A S_{D_{i}}}-h_{S A S_{S_{i}}}}{h_{S A S_{D_{i}}}}\right)^{2}, \sum_{i=1}^{N}\left(\frac{h_{I C U_{D_{i}}}-h_{I C U_{S_{i}}}}{h_{I C U_{D_{i}}}}\right)^{2}, \sum_{i=1}^{N}\left(\frac{h_{U F A_{D_{i}}}-h_{U F A_{S_{i}}}}{h_{U F A_{D_{i}}}}\right)^{2} \text {, and } \sum_{i=1}^{N}\left(\frac{L_{D_{i}}-L_{S_{i}}}{L_{D_{i}}}\right)^{2},
$$

where the heads in the SAS are $h_{S A S_{D_{i}}}$ and $h_{S A S_{S_{i}}}$, the heads in the ICU are $h_{I C U_{D_{i}}}$ and $h_{I C U_{S_{i}}}$, the heads in the UFA are $h_{U F A_{D_{i}}}$ and $h_{U F A_{S_{i}}}$, the leakage rates to the UFA are $L_{D_{i}}$ and $L_{S_{i}}$, and $N$ is the number of simulated or measured head or leakage rate points. The leakage rates to the UFA were computed from the application of Darcy's law:

$$
L_{D_{i}}=\frac{K_{z D}\left(h_{I C U_{D_{i}}}-h_{U F A_{D_{i}}}\right)}{b_{I C U, U F A}} \text { and } L_{S_{i}}=\frac{K_{z S}\left(h_{I C U_{S_{i}}}-h_{U F A_{S_{i}}}\right)}{b_{I C U, U F A}}
$$

where $b_{I C U, U F A}$ is the vertical distance between the center of the ICU and the UFA layers, and $K_{z D}$ and $K_{z S}$ are the equivalent vertical hydraulic conductivity between the lower half of the ICU and the upper half of the UFA layer, computed from Eq. (2) using the thicknesses of these two units.

\section{Composite hydraulic properties for model layer simplification of the unconfined aquifer and confining unit}

Eqs. (1)-(3) use lithologic thicknesses to calculate composite hydraulic properties to simplify model layering. However, the use of regression-based PE techniques (Halford, 2006) requires using the radial axisymmetric $2 \mathrm{D}$ flow models similar to the ones used to analyze the aquifer-test data, but with simplified model layers and calibrated to the same aquifertest data. The models that simulated the combined flow in the SAS and ICU as one lithologic unit (quasi-2D flow model) were developed assuming an ICU layer with zero specific storage and zero horizontal hydraulic conductivity in Eqs. (1) and (3), such that only vertical flow can occur in the ICU.

The most simplified flow model used a quasi-2D approach to represent the effect of only vertical flow in the ICU. In this approach, the head and storage changes in the ICU are not simulated. The performance of the two methods of computing composite hydraulic properties for the various simplified models was assessed by examining the aquifer test residuals between measured water levels in the SAS and the simulated water levels by the $2 \mathrm{D}$ radial axisymmetric flow models. The computed root-mean square residuals (RMSRs) for each well field were used to characterize the accuracy of each simplified model to simulate flow.

A comparison of all root-mean square residuals (RMSRs) between measured and simulated aquifer-test drawdown in the SAS at the Carrot Barn well field shows that the highest increase in RMSRs occurred from the highest layering discretization available, or the $8 \mathrm{LU}$ radial axisymmetric flow model, to the 3 LU or quasi-2D flow model (Table 1), whether using average hydraulic properties from Eqs. (1)-(3), or from a regression-based PE technique. Similarly, the highest increase in RMSRs at the Lyonia Preserve well field occurred from the highest lithologic unit discretization available, or the 6 LU radial 
axisymmetric flow model, to the $3 \mathrm{LU}$ or quasi-2D flow model (Table 2). The largest changes in flow characteristics occurred from fully $2 \mathrm{D}$ to quasi-2D models. In both cases, the regression-based PE technique resulted in lower RMSR values when compared to the methods that used Eqs. (1)-(3) to calculate composite hydraulic properties for the simplified layers in each model.

\begin{tabular}{|c|c|c|}
\hline \multirow{2}{*}{$\begin{array}{c}\text { Conceptual } \\
\text { Flow Model }\end{array}$} & \multicolumn{2}{|c|}{ RMSRs, in meters } \\
\cline { 2 - 3 } & Using Eqs. (1)-(3) & Using regression-based PE technique \\
\hline 8 LU (FPW) & Not applicable & $1.60 \times 10^{-2}$ \\
\hline $6 \mathrm{LU}(\mathrm{FPW})$ & $1.00 \times 10^{-1}$ & $3.65 \times 10^{-2}$ \\
\hline $4 \mathrm{LU}(\mathrm{FPW})$ & $3.18 \times 10^{-1}$ & $1.08 \times 10^{-1}$ \\
\hline $3 \mathrm{LU}(\mathrm{FPW})$ & $3.95 \times 10^{-1}$ & $1.98 \times 10^{-1}$ \\
\hline $8 \mathrm{LU}(\mathrm{PPW})$ & Not applicable & $7.00 \times 10^{-3}$ \\
\hline $6 \mathrm{LU}(\mathrm{PPW})$ & $1.72 \times 10^{-1}$ & $3.72 \times 10^{-2}$ \\
\hline $4 \mathrm{LU}(\mathrm{PPW})$ & $3.48 \times 10^{-1}$ & $1.98 \times 10^{-1}$ \\
\hline $3 \mathrm{LU}(\mathrm{PPW})$ & $3.96 \times 10^{-1}$ & $2.12 \times 10^{-1}$ \\
\hline
\end{tabular}

Table 1. Root-mean-square residuals (RMSRs) between measured and simulated drawdown at observation wells in the surficial aquifer system (SAS) of the Carrot Barn well field due to pumping from the fully (FPW) or partially penetrating well (PPW) tapping the SAS. [RMSRs were computed from the radial axisymmetric 2D flow models based on 3,335 and 3,367 measured drawdown points for the FPW and PPW tests, respectively, for the original 8 lithologic unit (LU) model and the simplified $6 \mathrm{LU}, 4 \mathrm{LU}$, and $3 \mathrm{LU}$ models; PE, parameter estimation. "Not applicable" indicates, for the $8 \mathrm{LU}$ (FPW) and $8 \mathrm{LU}$ (PPW) conceptual flow models, that these two are the highest layering discretization models available from aquifer tests, or not simplified models. For these, Eqs. (1)-(3) did not have to be used to generate parameters for simplified models]

Composite hydraulic properties for the simplified models derived from Eqs. (1)-(3) or from regression-based PE techniques at each well field showed that the largest variations occurred in the vertical hydraulic conductivity (Tables 3 and 4). The main difference between composite hydraulic properties for the simplified conceptual flow models derived from Eqs. (1)-(3) and from the regression-based PE technique was the composite vertical hydraulic conductivity derived for the 3 LU models for Lyonia Preserve, where the difference was one order of magnitude (Table 4). This difference could be explained by the contrasts in derived vertical hydraulic conductivity between the ICU and its overlying lithologic unit. Such a large contrast in vertical hydraulic conductivity between the ICU and its overlying unit was not observed in the Carrot Barn well field (Table 3). The largest increases in RMSRs from one conceptual model to another coincided with the largest contrast in vertical hydraulic conductivity between two contacting LUs. In particular, a large contrast in vertical hydraulic conductivity between the lowermost LU of the SAS and the ICU for the Lyonia Preserve models caused large increases in RMSRs. These large increases 
did not occur for the Carrot Barn models due to a smaller contrast in vertical hydraulic conductivity between the lowermost LU of the SAS and the ICU.

\begin{tabular}{|c|c|c|}
\hline \multirow{2}{*}{$\begin{array}{c}\text { Conceptual } \\
\text { Flow Model }\end{array}$} & \multicolumn{2}{|c|}{ RMSRs, in meters } \\
\cline { 2 - 3 } & Using Eqs. (1)-(3) & Using regression-based PE technique \\
\hline $6 \mathrm{LU}(\mathrm{FPW})$ & Not applicable & $4.09 \times 10^{-3}$ \\
\hline $5 \mathrm{LU}(\mathrm{FPW})$ & $6.78 \times 10^{-3}$ & $4.18 \times 10^{-3}$ \\
\hline $4 \mathrm{LU}(\mathrm{FPW})$ & $5.11 \times 10^{-3}$ & $4.19 \times 10^{-3}$ \\
\hline $3 \mathrm{LU}(\mathrm{FPW})$ & $2.58 \times 10^{-1}$ & $1.86 \times 10^{-1}$ \\
\hline $6 \mathrm{LU}(\mathrm{PPW})$ & Not applicable & $8.74 \times 10^{-3}$ \\
\hline $5 \mathrm{LU}(\mathrm{PPW})$ & $9.18 \times 10^{-3}$ & $8.76 \times 10^{-3}$ \\
\hline $4 \mathrm{LU}(\mathrm{PPW})$ & $8.85 \times 10^{-3}$ & $8.77 \times 10^{-3}$ \\
\hline $3 \mathrm{LU}(\mathrm{PPW})$ & $1.69 \times 10^{-1}$ & $1.33 \times 10^{-1}$ \\
\hline
\end{tabular}

Table 2. Root-mean-square residuals (RMSRs) between measured and simulated drawdown at observation wells in the surficial aquifer system (SAS) of the Lyonia Preserve well field due to pumping from the fully (FPW) or partially penetrating well (PPW) tapping the SAS. [RMSRs were computed from the radial axisymmetric 2D flow models based on 3,205 and 1,416 measured drawdown points for the FPW and PPW tests, respectively, for the original 6 lithologic unit (LU) model and the simplified $5 \mathrm{LU}, 4 \mathrm{LU}$, and $3 \mathrm{LU}$ models; PE, parameter estimation. "Not applicable" indicates, for the 6 LU (FPW) and 6 LU (PPW) conceptual flow models, that these two are the highest layering discretization models available from aquifer tests, or not simplified models. For these, Eqs. (1)-(3) did not have to be used to generate parameters for simplified models]

A substantially thicker UFA than the SAS or the ICU results in a larger transmissivity of the UFA than the SAS or ICU. This applies to both the Carrot Barn and the Lyonia Preserve sites. Hydraulic properties of the UFA for layer numbers 7 and 8 remained unchanged throughout the calculation of composite hydraulic properties because the hydraulic conductivity and thickness of the UFA is much greater than those of the ICU. Thus, pumping from the SAS does not generate a large enough stress to cause drawdown in the UFA. 


\begin{tabular}{|c|c|c|c|c|c|c|}
\hline $\begin{array}{l}\text { LU } \\
\text { number }\end{array}$ & $\begin{array}{l}6 \mathrm{LU} \\
\text { model } \\
\text { Eqs. (1)-(3) }\end{array}$ & $\begin{array}{l}6 \mathrm{LU} \\
\text { model PE }\end{array}$ & $\begin{array}{l}4 \text { LU } \\
\text { model } \\
\text { Eqs. (1)-(3) }\end{array}$ & $\begin{array}{l}4 \mathrm{LU} \\
\text { model PE }\end{array}$ & $\begin{array}{l}3 \text { LU } \\
\text { model } \\
\text { Eqs. (1)-(3) }\end{array}$ & $\begin{array}{l}3 \mathrm{LU} \\
\text { model PE }\end{array}$ \\
\hline SAS - 1 & $\begin{array}{l}1.59 \times 10^{-1} \\
1.53 \times 10^{-4} \\
1.71 \times 10^{-3}\end{array}$ & $\begin{array}{l}1.59 \times 10^{-1} \\
1.53 \times 10^{-4} \\
1.71 \times 10^{-3}\end{array}$ & \multirow{3}{*}{$\begin{array}{l}6.93 \times 10^{0} \\
1.64 \times 10^{-4} \\
1.13 \times 10^{-2}\end{array}$} & \multirow{3}{*}{$\begin{array}{l}7.94 \times 10^{0} \\
1.54 \times 10^{-4} \\
8.08 \times 10^{-2}\end{array}$} & \multirow{4}{*}{$\begin{array}{l}6.93 \times 10^{0} \\
1.64 \times 10^{-4} \\
5.22 \times 10^{-3}\end{array}$} & \multirow{4}{*}{$\begin{array}{l}5.67 \times 10^{0} \\
7.19 \times 10^{-5} \\
4.71 \times 10^{-3}\end{array}$} \\
\hline SAS - 2 & $\begin{array}{l}1.87 \times 10^{1} \\
9.93 \times 10^{-5} \\
2.65 \times 10^{0}\end{array}$ & $\begin{array}{l}1.87 \times 10^{1} \\
9.93 \times 10^{-5} \\
2.65 \times 10^{0}\end{array}$ & & & & \\
\hline $\begin{array}{l}\text { SAS - } 3 \\
\text { SAS - } 4 \\
\text { SAS - } 5\end{array}$ & $\begin{array}{l}1.11 \times 10^{0} \\
2.03 \times 10^{-4} \\
1.50 \times 10^{-2}\end{array}$ & $\begin{array}{l}6.60 \times 10^{-1} \\
3.20 \times 10^{-4} \\
8.05 \times 10^{-2} \\
\end{array}$ & & & & \\
\hline ICU - 6 & $\begin{array}{l}1.36 \times 10^{-2} \\
6.11 \times 10^{-4} \\
1.57 \times 10^{-3}\end{array}$ & $\begin{array}{l}1.36 \times 10^{-2} \\
6.11 \times 10^{-4} \\
1.57 \times 10^{-3}\end{array}$ & $\begin{array}{l}1.36 \times 10^{-2} \\
6.11 \times 10^{-4} \\
1.57 \times 10^{-3}\end{array}$ & $\begin{array}{l}1.36 \times 10^{-2} \\
6.11 \times 10^{-4} \\
1.57 \times 10^{-3}\end{array}$ & & \\
\hline $\begin{array}{l}\text { UFA - } 7 \\
\text { UFA - } 8\end{array}$ & $\begin{array}{l}3.01 \times 10^{1} \\
1.64 \times 10^{-6} \\
3.01 \times 10^{-1}\end{array}$ & $\begin{array}{l}3.01 \times 10^{1} \\
1.64 \times 10^{-6} \\
3.01 \times 10^{-1}\end{array}$ & $\begin{array}{l}3.01 \times 10^{1} \\
1.64 \times 10^{-6} \\
3.01 \times 10^{-1}\end{array}$ & $\begin{array}{l}3.01 \times 10^{1} \\
1.64 \times 10^{-6} \\
3.01 \times 10^{-1}\end{array}$ & $\begin{array}{l}3.01 \times 10^{1} \\
1.64 \times 10^{-6} \\
3.01 \times 10^{-1}\end{array}$ & $\begin{array}{l}3.01 \times 10^{1} \\
1.64 \times 10^{-6} \\
3.01 \times 10^{-1}\end{array}$ \\
\hline
\end{tabular}

Table 3. Hydraulic properties of the SAS, ICU, and UFA, for the simplified 6 LU, 4 LU, and 3 LU conceptual 2D radial axisymmetric flow models in the Carrot Barn well field, derived from the $8 \mathrm{LU}$ model properties either using Eqs. (1)-(3) or regression-based parameter estimation (PE) with MODOPTIM. [Listed properties are: horizontal hydraulic conductivity $(\mathrm{m} / \mathrm{d})$, specific storage $(1 / \mathrm{m})$, and vertical hydraulic conductivity $(\mathrm{m} / \mathrm{d})]$

\begin{tabular}{|c|c|c|c|c|c|c|}
\hline $\begin{array}{l}\text { LU } \\
\text { number }\end{array}$ & $\begin{array}{l}5 \mathrm{LU} \\
\text { model } \\
\text { Eqs. (1)-(3) }\end{array}$ & $\begin{array}{l}5 \mathrm{LU} \\
\text { model PE }\end{array}$ & $\begin{array}{l}4 \text { LU } \\
\text { model } \\
\text { Eqs. (1)-(3) }\end{array}$ & $\begin{array}{l}4 \mathrm{LU} \\
\text { model PE }\end{array}$ & $\begin{array}{l}3 \text { LU } \\
\text { model } \\
\text { Eqs. (1)-(3) }\end{array}$ & $\begin{array}{l}3 \mathrm{LU} \\
\text { model PE }\end{array}$ \\
\hline SAS - 1 & $\begin{array}{l}6.57 \times 10^{1} \\
4.91 \times 10^{-5} \\
3.29 \times 10^{0}\end{array}$ & $\begin{array}{l}6.57 \times 10^{1} \\
4.91 \times 10^{-5} \\
3.29 \times 10^{0}\end{array}$ & \multirow{3}{*}{$\begin{array}{l}6.22 \times 10^{1} \\
5.57 \times 10^{-5} \\
5.32 \times 10^{0}\end{array}$} & \multirow{3}{*}{$\begin{array}{l}6.29 \times 10^{1} \\
6.24 \times 10^{-5} \\
5.66 \times 10^{0}\end{array}$} & \multirow{4}{*}{$\begin{array}{l}6.22 \times 10^{1} \\
5.57 \times 10^{-5} \\
1.26 \times 10^{-3}\end{array}$} & \multirow{4}{*}{$\begin{array}{l}1.44 \times 10^{1} \\
1.19 \times 10^{-4} \\
4.39 \times 10^{-4}\end{array}$} \\
\hline SAS - 2 & & $6.28 \times 101$ & & & & \\
\hline SAS - 3 & $\begin{array}{l}6.15 \times 10^{1} \\
5.71 \times 10^{-5} \\
6.07 \times 10^{0}\end{array}$ & $\begin{array}{l}6.13 \times 10^{-5} \\
5.65 \times 10^{0}\end{array}$ & & & & \\
\hline ICU - 4 & $\begin{array}{l}4.38 \times 10^{-2} \\
9.08 \times 10^{-4} \\
4.38 \times 10^{-4}\end{array}$ & $\begin{array}{l}4.38 \times 10^{-2} \\
9.08 \times 10^{-4} \\
4.38 \times 10^{-4}\end{array}$ & $\begin{array}{l}4.38 \times 10^{-2} \\
9.08 \times 10^{-4} \\
4.38 \times 10^{-4}\end{array}$ & $\begin{array}{l}4.38 \times 10^{-2} \\
9.08 \times 10^{-4} \\
4.38 \times 10^{-4}\end{array}$ & & \\
\hline $\begin{array}{l}\text { UFA - } 5 \\
\text { UFA - } 6\end{array}$ & $\begin{array}{l}8.25 \times 10^{1} \\
1.64 \times 10^{-6} \\
8.25 \times 10^{-1}\end{array}$ & $\begin{array}{l}8.25 \times 10^{1} \\
1.64 \times 10^{-6} \\
8.25 \times 10^{-1}\end{array}$ & $\begin{array}{l}8.25 \times 10^{1} \\
1.64 \times 10^{-6} \\
8.25 \times 10^{-1}\end{array}$ & $\begin{array}{l}8.25 \times 10^{1} \\
1.64 \times 10^{-6} \\
8.25 \times 10^{-1}\end{array}$ & $\begin{array}{l}8.25 \times 10^{1} \\
1.64 \times 10^{-6} \\
8.25 \times 10^{-1}\end{array}$ & $\begin{array}{l}8.25 \times 10^{1} \\
1.64 \times 10^{-6} \\
8.25 \times 10^{-1}\end{array}$ \\
\hline
\end{tabular}

Table 4. Hydraulic properties of the SAS, ICU, and UFA, for the simplified 5 LU, 4 LU, and $3 \mathrm{LU}$ conceptual 2D radial axisymmetric flow models in the Lyonia Preserve well field, derived from the $6 \mathrm{LU}$ model properties either using Eqs. (1)-(3) or regression-based parameter estimation (PE) with MODOPTIM. [Listed properties are: horizontal hydraulic conductivity $(\mathrm{m} / \mathrm{d})$, specific storage $(1 / \mathrm{m})$, and vertical hydraulic conductivity $(\mathrm{m} / \mathrm{d})]$. 


\section{Evaluation of 3D models with simplified layers and hypothetical pumping of the confined aquifer}

Although water was pumped out of the SAS during the aquifer tests, transient 3D groundwater flow models simulating pumping from the UFA were needed to assess the effects of model layer simplification in the SAS and ICU on heads and flows in this twoaquifer system, because the UFA is the principal water supply. These 3D groundwater flow models, regional in nature, were developed to simulate temporal variations in recharge to the SAS and pumping from the UFA, and to evaluate how simulated flow changes in the SAS and UFA might be affected by model layering simplification through the computation of composite hydraulic properties for the SAS and ICU.

The maximum number of model layers simulated for each well field varied according to site lithology (Fig. 5). Each model had 400 rows and 400 columns, with no-flow conditions imposed along the lateral boundaries, either a constant-head or no-flow boundary at the bottom of the UFA, and a specified recharge rate imposed at the top of the SAS. Square cells $80.5 \mathrm{~m}$ long were used to span an area of about $1,037 \mathrm{~km}^{2}$ in models for each well field. Flow models used uniform hydraulic properties as shown in figure 5 for each simulated layer. Composite hydraulic properties for several lithologic units were calculated for the Carrot Barn and Lyonia Preserve models, as shown by the hydraulic properties applied to more than one unit in Tables 3 and 4. The composite hydraulic properties for the full thicknesses of the SAS and ICU units were calculated only for the 3 LU models, leaving the hydraulic properties of the UFA unchanged for all models.

Changes in SAS heads, ICU heads, UFA heads, and leakage rates to the UFA were analyzed with the transient 3D models using MODFLOW-2000 (Harbaugh et al. 2000). The combined flow of the SAS and the ICU was simulated by using a quasi-3D flow approximation (McDonald and Harbaugh 1988) where the composite hydraulic properties for these two units were calculated assuming zero horizontal hydraulic conductivity and zero specific storage in the ICU. The vertical hydraulic conductivity of the SAS and of the ICU are used in Eq. (2) in the quasi-3D flow approximation to compute the composite vertical hydraulic conductivity of the two, which results in a value closer to the less permeable lithologic unit. The assumption of no horizontal flow in the ICU in a quasi-3D flow approximation causes the SAS and ICU to be represented with a lower composite horizontal hydraulic conductivity from Eq. (1) than in a fully 3D flow simulation. The flow residuals simulated with a quasi-3D flow approximation are quantified and compared in this section with those of a fully 3D flow.

Flow in the UFA for all models was simulated with two layers with equal hydraulic properties. Hypothetical pumping wells tapped only the upper UFA lithologic unit (Fig. 5) to isolate the effects of pumping from the UFA on the induced flow from the SAS in each well field, to simulate a partial penetration of many pumping UFA wells in the area, and to better assess the effect of the boundary condition applied at the bottom of the lower UFA lithologic unit. The number of each LU in figure 5 refers to the vertical zones within the SAS, ICU, and UFA that have distinctive hydraulic properties. Each vertical zone or LU within the SAS, ICU, and UFA was further divided into two model layers with half the thickness and the same hydraulic properties for each LU in Tables 3 and 4 to increase the resolution of the simulated vertical hydraulic gradients.

Variable monthly recharge rates (Fig. 6a) were simulated, during a one-year period, in the top 3D flow model layer of the SAS. Total simulated recharge to the SAS was $50.8 \mathrm{~cm} /$ year, 
a reasonable average estimate for the area. This reasonable average recharge rate to the SAS was used to discard recharge as a variable that could contribute to water level residuals at observations wells in the SAS. The top 3D flow model simulates the effects of recharge, hydraulic conductivity, pumping rates, and initial heads on simulated heads in the SAS, ICU, and UFA. Variable monthly pumping rates were applied to six hypothetical UFA wells distributed near the center of the grid (Fig. 6b). Measured heads in the SAS, ICU, and UFA from nearby observation wells were used to specify initial heads for the 3D flow models. The main hydraulic parameter that causes variations in head residuals and changes in leakage rates to the ICU is the horizontal and vertical hydraulic conductivity.
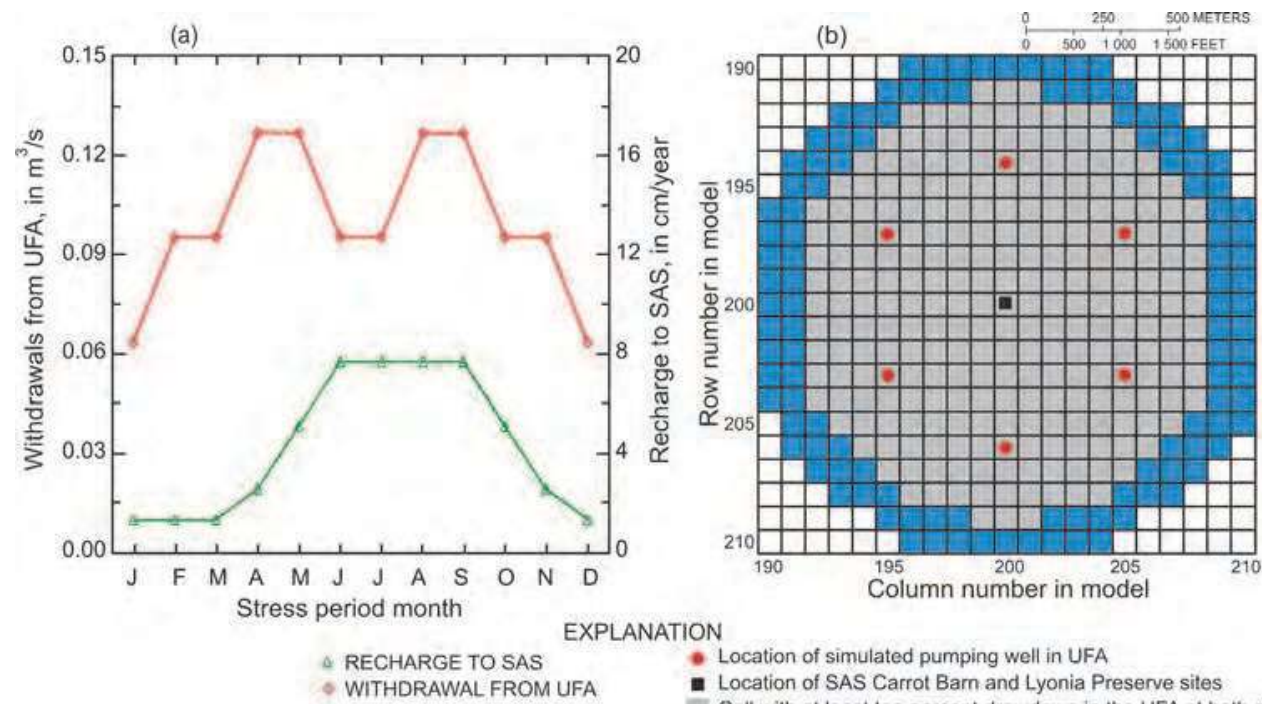

Location of simulated pumping well in UFA
Cocation of SAS Carrot Barn and Lyonia Preserve sites
Additional cell at Lyonia Preserve site with at least ten percent

Additional cell at Lyonia
drawdown in the UFA

Fig. 6. (a) Simulated monthly recharge and pumping rates and (b) locations of simulated pumping wells from the Upper Floridan aquifer in each model.

The simulated heads in the SAS, ICU, and UFA, and the simulated leakage rates to the UFA with the $8 \mathrm{LU}$ model for the Carrot Barn well field or with the $6 \mathrm{LU}$ model for the Lyonia Preserve well field were used as the "observed" heads and flows to calculate residuals resulting from model layer simplification. The accuracy of the methods used to compute composite hydraulic properties (Eqs. (1)-(3) and PE) for the simplified 3D flow models was assessed by examining the RMSRs between observed and simulated SAS heads, ICU heads, UFA heads, and leakage rates to the UFA from the overlying ICU unit. The largest RMSRs were calculated when the composite hydraulic properties for the combined SAS and ICU lithologic units were used to simulate a single layer (Tables 5, 6). The increase in SAS, ICU, and UFA head RMSRs from a fully 3D to a quasi-3D model was the largest for both Lyonia Preserve and Carrot Barn simulations than any other single-step transition in conceptual flow models. The difference in vertical hydraulic conductivity between the lowermost LU of the SAS and the ICU was the main reason for the increases in residuals.

Leakage rates from the SAS to the UFA, in these areas characterized as recharging the UFA, were simulated using Eq. (5), the assigned hydraulic conductivity to the UFA by McGurk 
and Presley (2002), and a vertical to horizontal hydraulic conductivity anisotropy of 0.01 in the vicinity of the Carrot Barn and Lyonia Preserve well fields. RMSRs for the leakage rates to the UFA and heads in the ICU simulated by the quasi-3D models were among the largest from all conceptual flow models (Tables 5, 6). Head and leakage RMSR rates were calculated relative to the highest vertically discretized models $(6 \mathrm{LU}$ model for Carrot Barn and $5 \mathrm{LU}$ model for Lyonia Preserve). The largest RMSR percentages were simulated for the heads in the UFA by the quasi-3D model for the Lyonia Preserve well field when the no-flow boundary was imposed at the bottom of the UFA lower layer (Table 6B). The largest contrasts in vertical hydraulic conductivity between the ICU and the LUs lying above or below occurred at the Lyonia Preserve well field (Table 4, Fig. 5b).

\begin{tabular}{|c|c|c|c|c|c|c|c|c|}
\hline \multirow{3}{*}{ Model } & \multicolumn{8}{|c|}{$\begin{array}{l}\text { (A) Root-mean-square residuals, constant-head boundary } \\
\text { applied at the bottom of the UFA }\end{array}$} \\
\hline & \multicolumn{2}{|c|}{$\begin{array}{l}\text { SAS heads } \\
(\mathrm{m})\end{array}$} & \multicolumn{2}{|c|}{$\begin{array}{l}\text { ICU heads } \\
(\mathrm{m})\end{array}$} & \multicolumn{2}{|c|}{$\begin{array}{l}\text { UFA heads } \\
\qquad(\mathrm{m})\end{array}$} & \multicolumn{2}{|c|}{$\begin{array}{l}\text { Leakage rates to } \\
\text { UFA (cm/year) }\end{array}$} \\
\hline & $\begin{array}{l}\text { Eqs. } \\
(1)-(3)\end{array}$ & PE & $\begin{array}{l}\text { Eqs. } \\
(1)-(3)\end{array}$ & PE & $\begin{array}{l}\text { Eqs. } \\
(1)-(3)\end{array}$ & PE & $\begin{array}{l}\text { Eqs. } \\
(1)-(3)\end{array}$ & $\mathrm{PE}$ \\
\hline $6 \mathrm{LU}$ & $\begin{array}{c}0.05 \\
(0.26)\end{array}$ & $\begin{array}{c}0.26 \\
(1.40)\end{array}$ & $\begin{array}{c}0.02 \\
(0.11)\end{array}$ & $\begin{array}{c}0.07 \\
(0.45)\end{array}$ & $\begin{array}{c}0.00 \\
(0.00)\end{array}$ & $\begin{array}{c}0.00 \\
(0.00)\end{array}$ & $\begin{array}{c}0.41 \\
(2.84)\end{array}$ & $\begin{array}{c}1.48 \\
(11.61)\end{array}$ \\
\hline $4 \mathrm{LU}$ & $\begin{array}{c}0.05 \\
(0.24)\end{array}$ & $\begin{array}{c}0.35 \\
(1.87)\end{array}$ & $\begin{array}{c}0.02 \\
(0.13)\end{array}$ & $\begin{array}{c}0.11 \\
(0.68)\end{array}$ & $\begin{array}{c}0.00 \\
(0.00)\end{array}$ & $\begin{array}{c}0.01 \\
(0.05)\end{array}$ & $\begin{array}{c}0.43 \\
(3.23)\end{array}$ & $\begin{array}{c}2.15 \\
(16.06)\end{array}$ \\
\hline $3 \mathrm{LU}$ & $\begin{array}{c}0.15 \\
(0.83)\end{array}$ & $\begin{array}{c}0.24 \\
(1.30)\end{array}$ & $\begin{array}{c}1.43 \\
(8.71)\end{array}$ & $\begin{array}{l}1.43 \\
(8.71)\end{array}$ & $\begin{array}{c}0.04 \\
(0.27)\end{array}$ & $\begin{array}{c}0.03 \\
(0.22)\end{array}$ & $\begin{array}{c}13.36 \\
(100.2)\end{array}$ & $\begin{array}{c}10.97 \\
(82.19)\end{array}$ \\
\hline \multirow{3}{*}{ Model } & \multicolumn{8}{|c|}{$\begin{array}{l}\text { (B) Root-mean-square residuals, no-flow boundary } \\
\text { applied at the bottom of the UFA }\end{array}$} \\
\hline & \multicolumn{2}{|c|}{$\begin{array}{l}\text { SAS heads } \\
(\mathrm{m})\end{array}$} & \multicolumn{2}{|c|}{$\begin{array}{l}\text { ICU heads } \\
(\mathrm{m})\end{array}$} & \multicolumn{2}{|c|}{$\begin{array}{l}\text { UFA heads } \\
\text { (m) }\end{array}$} & \multicolumn{2}{|c|}{$\begin{array}{l}\text { Leakage rates to } \\
\text { UFA (cm/year) }\end{array}$} \\
\hline & $\begin{array}{l}\text { Eqs. } \\
(1)-(3)\end{array}$ & PE & $\begin{array}{l}\text { Eqs. } \\
(1)-(3)\end{array}$ & $\mathrm{PE}$ & $\begin{array}{l}\text { Eqs. } \\
(1)-(3)\end{array}$ & $\mathrm{PE}$ & $\begin{array}{l}\text { Eqs. } \\
(1)-(3)\end{array}$ & $\mathrm{PE}$ \\
\hline $6 \mathrm{LU}$ & $\begin{array}{c}0.02 \\
(0.13)\end{array}$ & $\begin{array}{c}0.09 \\
(0.57)\end{array}$ & $\begin{array}{c}0.06 \\
(0.65)\end{array}$ & $\begin{array}{c}0.34 \\
(3.78)\end{array}$ & $\begin{array}{c}0.04 \\
(0.48)\end{array}$ & $\begin{array}{l}0.17 \\
(2.30)\end{array}$ & $\begin{array}{c}0.57 \\
(1.75)\end{array}$ & $\begin{array}{c}4.09 \\
(16.13)\end{array}$ \\
\hline $4 \mathrm{LU}$ & $\begin{array}{c}0.08 \\
(0.52)\end{array}$ & $\begin{array}{c}0.30 \\
(1.97)\end{array}$ & $\begin{array}{c}0.03 \\
(0.28)\end{array}$ & $\begin{array}{c}0.44 \\
(4.82)\end{array}$ & $\begin{array}{c}0.01 \\
(0.19)\end{array}$ & $\begin{array}{c}0.22 \\
(2.82)\end{array}$ & $\begin{array}{c}0.65 \\
(2.30)\end{array}$ & $\begin{array}{c}4.74 \\
(16.79)\end{array}$ \\
\hline $3 \mathrm{LU}$ & $\begin{array}{c}0.30 \\
(1.92)\end{array}$ & $\begin{array}{c}1.63 \\
(10.72)\end{array}$ & $\begin{array}{c}2.81 \\
(29.90)\end{array}$ & $\begin{array}{c}3.81 \\
(38.57)\end{array}$ & $\begin{array}{c}0.63 \\
(7.29)\end{array}$ & $\begin{array}{c}2.29 \\
(24.95)\end{array}$ & $\begin{array}{c}20.21 \\
(78.22)\end{array}$ & $\begin{array}{c}13.37 \\
(57.81)\end{array}$ \\
\hline
\end{tabular}

Table 5. Root-mean-square residuals (percentages between parenthesis) between simulated SAS heads, ICU heads, UFA heads, and leakage rates to the UFA by the three-dimensional 8 LU flow model and those simulated by the $6 \mathrm{LU}, 4 \mathrm{LU}$, and $3 \mathrm{LU}$ simplified flow models for the aquifer stresses shown in figure 6a applied to the Carrot Barn well field. [Hydraulic properties were derived from either Eqs. (1)-(3) or from regression-based parameter estimation (PE) in Table 3] 


\begin{tabular}{|c|c|c|c|c|c|c|c|c|}
\hline \multirow{3}{*}{ Model } & \multicolumn{8}{|c|}{$\begin{array}{l}\text { (A) Root-mean-square residuals, constant-head boundary } \\
\text { applied at the bottom of the UFA }\end{array}$} \\
\hline & \multicolumn{2}{|c|}{$\begin{array}{l}\text { SAS heads } \\
(\mathrm{m})\end{array}$} & \multicolumn{2}{|c|}{$\begin{array}{l}\text { ICU heads } \\
\qquad(\mathrm{m})\end{array}$} & \multicolumn{2}{|c|}{$\begin{array}{l}\text { UFA heads } \\
\text { (m) }\end{array}$} & \multicolumn{2}{|c|}{$\begin{array}{l}\text { Leakage rates to } \\
\text { UFA (cm/year) }\end{array}$} \\
\hline & $\begin{array}{l}\text { Eqs. } \\
(1)-(3)\end{array}$ & PE & $\begin{array}{l}\text { Eqs. } \\
(1)-(3)\end{array}$ & PE & $\begin{array}{l}\text { Eqs. } \\
(1)-(3)\end{array}$ & PE & $\begin{array}{l}\text { Eqs. } \\
(1)-(3)\end{array}$ & PE \\
\hline $5 \mathrm{LU}$ & $\begin{array}{c}0.00 \\
(0.00)\end{array}$ & $\begin{array}{c}0.00 \\
(0.00)\end{array}$ & $\begin{array}{c}0.00 \\
(0.00)\end{array}$ & $\begin{array}{c}0.00 \\
(0.00)\end{array}$ & $\begin{array}{c}0.00 \\
(0.00)\end{array}$ & $\begin{array}{c}0.00 \\
(0.00)\end{array}$ & $\begin{array}{c}0.00 \\
(0.00)\end{array}$ & $\begin{array}{c}0.01 \\
(0.22)\end{array}$ \\
\hline $4 \mathrm{LU}$ & $\begin{array}{c}0.00 \\
(0.00)\end{array}$ & $\begin{array}{c}0.01 \\
(0.11)\end{array}$ & $\begin{array}{c}0.00 \\
(0.00)\end{array}$ & $\begin{array}{c}0.00 \\
(0.00)\end{array}$ & $\begin{array}{c}0.00 \\
(0.00)\end{array}$ & $\begin{array}{c}0.00 \\
(0.00)\end{array}$ & $\begin{array}{c}0.00 \\
(0.00)\end{array}$ & $\begin{array}{c}0.02 \\
(0.41)\end{array}$ \\
\hline $3 \mathrm{LU}$ & $\begin{array}{c}0.35 \\
(5.49)\end{array}$ & $\begin{array}{c}1.71 \\
(25.86)\end{array}$ & $\begin{array}{c}0.44 \\
(9.24)\end{array}$ & $\begin{array}{c}1.02 \\
(22.13)\end{array}$ & $\begin{array}{c}0.01 \\
(0.19)\end{array}$ & $\begin{array}{c}0.00 \\
(0.00)\end{array}$ & $\begin{array}{c}5.70 \\
(103.5)\end{array}$ & $\begin{array}{c}0.22 \\
(2.21)\end{array}$ \\
\hline \multirow{3}{*}{ Model } & \multicolumn{8}{|c|}{$\begin{array}{l}\text { (B) Root-mean-square residuals, no-flow boundary } \\
\text { applied at the bottom of the UFA }\end{array}$} \\
\hline & \multicolumn{2}{|c|}{$\begin{array}{l}\text { SAS heads } \\
\quad(\mathrm{m})\end{array}$} & \multicolumn{2}{|c|}{$\begin{array}{l}\text { ICU heads } \\
(\mathrm{m})\end{array}$} & \multicolumn{2}{|c|}{$\begin{array}{l}\text { UFA heads } \\
\qquad(\mathrm{m})\end{array}$} & \multicolumn{2}{|c|}{$\begin{array}{l}\text { Leakage rates to } \\
\text { UFA }(\mathrm{cm} / \text { year })\end{array}$} \\
\hline & $\begin{array}{l}\text { Eqs. } \\
(1)-(3)\end{array}$ & PE & $\begin{array}{l}\text { Eqs. } \\
(1)-(3)\end{array}$ & PE & $\begin{array}{l}\text { Eqs. } \\
(1)-(3)\end{array}$ & PE & $\begin{array}{l}\text { Eqs. } \\
(1)-(3)\end{array}$ & PE \\
\hline $5 \mathrm{LU}$ & $\begin{array}{c}0.00 \\
(0.00)\end{array}$ & $\begin{array}{c}0.02 \\
(0.24)\end{array}$ & $\begin{array}{c}0.00 \\
(0.00)\end{array}$ & $\begin{array}{c}0.02 \\
(0.32)\end{array}$ & $\begin{array}{c}0.00 \\
(0.00)\end{array}$ & $\begin{array}{c}0.02 \\
(0.41)\end{array}$ & $\begin{array}{c}0.01 \\
(0.07)\end{array}$ & $\begin{array}{c}0.03 \\
(0.32)\end{array}$ \\
\hline $4 \mathrm{LU}$ & $\begin{array}{c}0.00 \\
(0.00)\end{array}$ & $\begin{array}{c}0.04 \\
(0.49)\end{array}$ & $\begin{array}{c}0.00 \\
(0.00)\end{array}$ & $\begin{array}{c}0.04 \\
(0.66)\end{array}$ & $\begin{array}{c}0.00 \\
(0.00)\end{array}$ & $\begin{array}{c}0.04 \\
(0.80)\end{array}$ & $\begin{array}{c}0.01 \\
(0.06)\end{array}$ & $\begin{array}{c}0.02 \\
(0.25)\end{array}$ \\
\hline $3 \mathrm{LU}$ & $\begin{array}{c}12.91 \\
(157.8)\end{array}$ & $\begin{array}{c}5.28 \\
(64.80)\end{array}$ & $\begin{array}{l}13.73 \\
(247.3)\end{array}$ & $\begin{array}{c}5.39 \\
(95.09)\end{array}$ & $\begin{array}{l}13.14 \\
(269.0)\end{array}$ & $\begin{array}{c}4.75 \\
(91.70)\end{array}$ & $\begin{array}{c}10.57 \\
(129.1)\end{array}$ & $\begin{array}{c}1.34 \\
(14.88)\end{array}$ \\
\hline
\end{tabular}

Table 6. Root-mean-square residuals (percentages between parenthesis) between simulated SAS heads, ICU heads, UFA heads, and leakage rates to the UFA by the three-dimensional 6 LU flow model and those simulated by the 5 LU, 4 LU, and 3 LU simplified flow models for the aquifer stresses shown in figure 6a applied to the Lyonia Preserve well field. [Hydraulic properties were derived from either Eqs. (1)-(3) or from regression-based parameter estimation (PE) in Table 4] 
Results from the calculated composite hydraulic properties suggest that the net effect on flow accuracy of transitioning from a fully $3 \mathrm{D}$ to a quasi-3D model lies somewhere between the residuals in Tables $5 \mathrm{~A}$ and $5 \mathrm{~B}$ and in Tables $6 \mathrm{~A}$ and $6 \mathrm{~B}$. The flow differences between the fully $3 \mathrm{D}$ and quasi-3D models increase when the no-flow boundary is simulated at the bottom of the UFA lower layer instead of the constant-head boundary case because downward flow to the UFA is induced from the overlying SAS with a more contrasting vertical hydraulic conductivity than the value used for the fully $3 \mathrm{D}$ flow model. A constanthead boundary at the bottom of the UFA lower layer induces increased flows through the constant-head boundary because the hydraulic conductivity of the UFA is higher than that of the ICU.

Leaky confining unit thicknesses at Carrot Barn and Lyonia Preserve of 10.7 and $4.9 \mathrm{~m}$, respectively (Fig. 5), were not thick enough to constitute a significant source of water from storage to cause a change in UFA heads. Flow simulations, assuming a hypothetical increase in the thickness of the ICU unit at the Carrot Barn and Lyonia Preserve well fields by one order of magnitude, were conducted to assess the effects of these thicknesses on changes in heads in the UFA. Simulation results showed the RMSRs in heads in the SAS, ICU, and UFA, and leakage rates to the UFA were reduced from 1.63, 3.81, and $2.29 \mathrm{~m}$, and 13.37 $\mathrm{cm} /$ year (Table 5B) for the Carrot Barn well field to 0.93, 2.01, and $1.40 \mathrm{~m}$, and $5.29 \mathrm{~cm} /$ year, respectively, when using the composite hydraulic properties derived from the regressionbased PE technique for the quasi-3D models after hypothetically increasing the thickness of the ICU by one order of magnitude. Corresponding flow simulations for the Lyonia Preserve well field resulted in RMSR changes from 5.28, 5.39, and $4.75 \mathrm{~m}$, and $1.34 \mathrm{~cm}$ /year to $4.22,2.19,1.46 \mathrm{~m}$, and $1.04 \mathrm{~cm}$ /year. These head and leakage rate residuals suggest that for a thick confining unit where storage effects may be important, application of the quasi3D approach may mask conceptual error because residual error may be reduced through the adjustment of composite hydraulic properties.

\section{Conclusions}

Conceptual flow models with decreasing numbers of model layers in an unconfined aquifer were developed to determine the effects on flow of calculating composite hydraulic properties from two or more lithologic units at a time. The thickness-weighted arithmetic mean was used to compute the horizontal hydraulic conductivity and the specific storage, and the thickness-weighted harmonic mean was used to compute the vertical hydraulic conductivity. A regression-based parameter estimation technique was also used to compute composite hydraulic properties. Flow in the unconfined aquifer can be simulated with reasonable accuracy if all lithologic units within the aquifer are combined into a single model layer, composite hydraulic properties are calculated from thickness-weighted averages, and the contrast in vertical hydraulic conductivity among the lithologic units is not large. The same level of accuracy cannot be achieved with composite properties when only vertical flow is simulated within the confining unit because of the increases in head residuals in the unconfined aquifer, confining unit, and confined aquifer, and increases in leakage rate residuals to the confined aquifer that occurred with the quasi-3D approach.

These residuals, which illustrate the main difference between the quasi-3D and fully $3 \mathrm{D}$ conceptual flow models, become larger as the contrast in vertical hydraulic conductivity between the lower lithologic units of the unconfined aquifer and the confining unit increases. 
The derivation of composite hydraulic properties for several lithologic units through regression-based parameter estimation techniques resulted in lower drawdown residuals in the $2 \mathrm{D}$ flow simulations when compared to the residuals derived from composite hydraulic properties derived from thickness-weighted averages. The same composite hydraulic properties derived from the parameter-estimation techniques resulted in higher simulated head and leakage rate residuals than those from thickness-weighted averages in the 3D flow simulations, which considered recharge to the unconfined aquifer and pumping from the confined aquifer. The lack of accuracy in heads and leakage rates can be explained by the contrasts in vertical hydraulic conductivity between the unconfined aquifer and the confining unit. Differences in specific storage were a small factor in the head and leakage rate residuals because the confining units of both well fields analyzed in this study were thin. As the thickness of the confining unit increases, larger water volumes from storage would be neglected by the quasi-3D flow simulations and differences in simulated heads in the confined aquifer could be larger than those presented in this chapter.

The derivation of composite hydraulic properties using regression-based parameter estimation techniques for the combined flow properties of the unconfined aquifer and the leaky confining unit showed that residuals for the water levels in the unconfined aquifer, heads in the confined aquifer, and leakage rates to the confined aquifer could be reasonably reduced when all lithologic units in the unconfined aquifer were simulated as one. These residuals increase when the composite hydraulic properties of the unconfined aquifer and the leaky confining unit are calculated, namely when the quasi-2D or quasi-3D flow assumptions are made. Given the flow residuals presented in this chapter, inaccuracies in simulated flow increase when a transition in conceptual flow models is made from a fully $3 \mathrm{D}$ to a quasi-3D flow simulation. When composite hydraulic properties are calculated for the simplified conceptual flow models, the head and leakage rate residuals increase as the contrast in hydraulic properties between the unconfined aquifer and the leaky confining unit increase, in particular, as the contrast in vertical hydraulic conductivity increases between these two lithologic units.

\section{References}

Alley, W.M.; Reilly, T.E. \& Franke, O.L. (1999). Sustainability of Groundwater Resources. US Geological Survey Circular 1186, Washington, DC.

Bouwer, H. (1978). Groundwater hydrology. McGraw Hill, ISBN 0070067155, New York.

Bouwer, H. \& Rice, R.C. (1976). A slug test for determining hydraulic conductivity of unconfined aquifers with completely or partially penetrating wells. Water Resources Research, Vol. 12, No. 3, pp. 423-428.

Clarke, R.; Lawrence, A.; \& Foster, S. (1996). Groundwater: A Threatened Resource (United Nations Environment Programme Environment Library No. 15, Nairobi, Kenya.

Copty, N.K.; Sarioglu, M.S. \& Findikakis, A.N. (2006). Equivalent transmissivity of heterogeneous leaky aquifers for steady state radial flow. Water Resources Research, Vol. 42, No. 4, W04416, doi: 10.1029/2005WR004673.

Domenico, P.A. (1972). Concepts and models in groundwater hydrology. McGraw Hill, ISBN 0070175357, New York.

Feng, C.Y.; Lee T.H.; Lee W.S. \& Chen C.H. (2007). Estimating finite difference block equivalent hydraulic conductivity for numerically solving the Richards' equation. Hydrological Processes Vol. 21, pp. 3587-3600. 
Halford, K.J. (2006). MODOPTIM: A general optimization program for ground water flow model calibration and ground water management with MODFLOW. US Geological Survey Scientific Investigations Report 2006-5009.

Hantush, M.S. (1964). Hydraulics of wells. Advances in Hydroscience 1, V.T. Chow, pp. 281432, Academic Press, New York.

Harbaugh, A.W. \& McDonald, M.G. (1996). User's documentation for MODFLOW-96, an update to the U.S. Geological Survey modular finite-difference ground-water flow model. US Geological Survey Open-File Report 96-485.

Harbaugh, A.W.; Banta, E.R.; Hill, M.C.; \& McDonald, M.G. (2000). MODFLOW-2000, the U.S. Geological Survey modular ground-water model - User guide to modularization concepts and the ground-water flow process. US Geological Survey Open-File Report 02-92.

Hill, M.C. \& Tiedeman C.R. (2007). Effective groundwater model calibration - with analysis of data, sensitivities, predictions, and uncertainty. Wiley, ISBN: 978-0-471-77636-9, New Jersey.

Langevin, C.D. (2008). Modeling axisymmetric flow and transport. Ground Water, Vol. 46, No. 4, pp. 579-590.

McDonald, M.G. \& Harbaugh, A.W. (1988). A modular 3D finite-difference ground-water flow model. US Geological Survey Techniques of Water-Resources Investigation Book 6, Chap. A1.

McGurk, B. \& Presley, P. (2002). Simulation of the effects of groundwater withdrawals on the Floridan aquifer system in east-central Florida: model expansion and revision. St. Johns River Water Management District Technical Paper 2002-3.

Miller, J.A. (1986). Hydrogeologic framework of the Floridan aquifer system in Florida and in parts of Georgia, Alabama, and South Carolina. US Geological Survey Professional Paper 1403-B.

Poeter, E.P.; Hill, M.C.; Banta, E.R.; Mehl, S. \& Christensen, S. (2005). UCODE_2005 and Six Other Computer Codes for Universal Sensitivity Analysis, Calibration, and Uncertainty Evaluation. US Geological Survey Techniques and Methods 6-A11, Reston, Virginia.

Reilly, T.E. \& Harbaugh, A.W. (1993). Computer note: Simulation of cylindrical flow to a well using the U.S. Geological Survey modular finite-difference ground-water flow model. Ground Water, Vol. 31, No. 3, pp. 489-494.

Sánchez-Vila, X.; Carrera, J. \& Girardi, J.P. (1996). Scale effects in transmissivity. J Hydrology, Vol. 183, pp. 1-22.

Sepúlveda, N. (2002). Simulation of ground-water flow in the intermediate and Floridan aquifer systems in peninsular Florida: US Geological Survey Scientific Investigations Report 2002-4009.

Solley, W.B.; Pierce, R.R.; \& Perlman, H.A. (1998). Estimated Use of Water in the United States in 1995. US Geological Survey Circular 1200, Washington, DC.

Snyder, J.P. (1987). Map projections-A working manual, $3^{\text {rd }}$ ed. US Geological Survey Professional Paper 1395, Washington, DC.

Van der Kamp, G. (1976). Determining aquifer transmissivity by means of well response tests: the underdamped case: Water Resources Research, Vol. 12, No. 1, pp. 71-77.

Walton, W.C. (2008). Upgrading aquifer test analysis. Ground Water, Vol. 46, No. 5, pp. 660662. 
Ward, A.L.; Zhang, Z.F. \& Gee, G.W. (2006). Upscaling unsaturated hydraulic parameters for flow through heterogeneous anisotropic sediments. Advances in Water Resources, Vo. 29, No. 2, pp. 268-280.

Wen, X.H. \& Gómez-Hernández, J.J. (1996). Upscaling hydraulic conductivities in heterogeneous media: An overview. J Hydrology, Vol. 183, pp. ix-xxxii. 


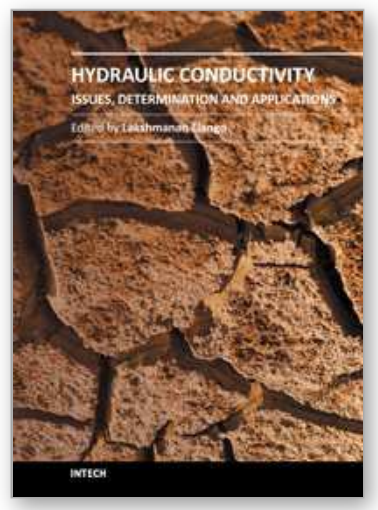

\author{
Hydraulic Conductivity - Issues, Determination and Applications \\ Edited by Prof. Lakshmanan Elango
}

ISBN 978-953-307-288-3

Hard cover, 434 pages

Publisher InTech

Published online 23, November, 2011

Published in print edition November, 2011

There are several books on broad aspects of hydrogeology, groundwater hydrology and geohydrology, which do not discuss in detail on the intrigues of hydraulic conductivity elaborately. However, this book on Hydraulic Conductivity presents comprehensive reviews of new measurements and numerical techniques for estimating hydraulic conductivity. This is achieved by the chapters written by various experts in this field of research into a number of clustered themes covering different aspects of hydraulic conductivity. The sections in the book are: Hydraulic conductivity and its importance, Hydraulic conductivity and plant systems, Determination by mathematical and laboratory methods, Determination by field techniques and Modelling and hydraulic conductivity. Each of these sections of the book includes chapters highlighting the salient aspects and most of these chapters explain the facts with the help of some case studies. Thus this book has a good mix of chapters dealing with various and vital aspects of hydraulic conductivity from various authors of different countries.

\title{
How to reference
}

In order to correctly reference this scholarly work, feel free to copy and paste the following:

Nicasio Sepúlveda and Eve L. Kuniansky (2011). Effects of Model Layer Simplification Using Composite Hydraulic Properties, Hydraulic Conductivity - Issues, Determination and Applications, Prof. Lakshmanan Elango (Ed.), ISBN: 978-953-307-288-3, InTech, Available from: http://www.intechopen.com/books/hydraulicconductivity-issues-determination-and-applications/effects-of-model-layer-simplification-using-compositehydraulic-properties

\section{INTECH}

open science | open minds

\section{InTech Europe}

University Campus STeP Ri

Slavka Krautzeka 83/A

51000 Rijeka, Croatia

Phone: +385 (51) 770447

Fax: +385 (51) 686166

www.intechopen.com

\section{InTech China}

Unit 405, Office Block, Hotel Equatorial Shanghai

No.65, Yan An Road (West), Shanghai, 200040, China

中国上海市延安西路 65 号上海国际贵都大饭店办公楼 405 单元

Phone: +86-21-62489820

Fax: $+86-21-62489821$ 
(C) 2011 The Author(s). Licensee IntechOpen. This is an open access article distributed under the terms of the Creative Commons Attribution 3.0 License, which permits unrestricted use, distribution, and reproduction in any medium, provided the original work is properly cited. 